Originally published as:

Ergünay, K., Saygan, M.B., Aydoğan, S., Litzba, N., Şener, B., Lederer, S., Niedrig, M., Hasçelik, G., Us, D.

Confirmed Exposure to Tick-Borne Encephalitis Virus and Probable Human Cases of TickBorne Encephalitis in Central/Northern Anatolia, Turkey

(2011) Zoonoses and Public Health, 58 (3), pp. 220-227.

DOI: $10.1111 / \mathrm{j} .1863-2378.2010 .01342 . x$

This is an author manuscript. The definitive version is available at: http://onlinelibrary.wiley.com/ 


\title{
Confirmed Exposure to Tick-Borne Encephalitis Virus and Probable Human Cases of Tick-Borne Encephalitis in Central/ Northern Anatolia, Turkey
}

\author{
K. Ergünay ${ }^{1}$, M. B. Saygan², S. Aydoğan ${ }^{1}$, N. Litzba ${ }^{3}$, B. Şener ${ }^{1}$, S. Lederer ${ }^{4}$, M. Niedrig ${ }^{3}$, G. Hascelik $^{1}$ \\ and D. Us \\ ${ }^{1}$ Department of Medical Microbiology, Faculty of Medicine, Hacettepe University, Ankara, Turkey \\ ${ }_{2}^{2}$ Middle Anatolia Regional Blood Center, Turkish Red Crescent Society, Ankara, Turkey \\ ${ }^{3}$ Center for Biological Safety (ZBS-1), Robert Koch Institute, Berlin, Germany \\ ${ }^{4}$ Tropical Diseases Department, Euroimmun AG, Lubeck, Germany
}

\begin{abstract}
Tick-borne encephalitis virus (TBEV) is the aetiological agent of tick-borne encephalitis (TBE), a potentially fatal central nervous system infection of humans. TBE is endemic in many areas of Europe and Asia; however, very scarce data on TBEV activity are available from Turkey. We aimed to identify TBEV exposure in healthy blood donors and the impact of TBEV in central nervous system infections in Central/Northern Anatolia. Two-thousand four hundred and fifty four sera, collected from blood donors at Ankara, Konya, Eskişehir and Zonguldak branches of the Turkish Red Crescent Middle Anatolia Regional Blood Center, were analysed for TBEV serosurveillance. Paired serum and cerebrospinal fluid samples from 108 patients with the diagnosis of aseptic meningitis/encephalitis of unknown aetiology were also evaluated to identify TBE and neuroborreliosis cases. Commercial enzyme-linked immunosorbent assays and indirect immunofluorescence tests were employed for antibody detection. Forty-seven donor samples (1.9\%) were reactive for TBEV IgG. In 25 persons with IgG reactivity (53.1\%), risk factors for tick-borne infections were revealed. One sample from Zonguldak province (1/198; $0.5 \%)$ in the Black Sea region of Turkey was confirmed to possess neutralizing antibodies via plaque reduction neutralization test. TBEV IgM was detected in $7.4 \%$ (8/108) of the patients. IgM was accompanied by IgG reactivity in two persons where, in one, recent history of a tick bite was also identified. Intrathecal antibody production for TBEV could not be demonstrated. No evidence for Borrelia infections could be found. Confirmed exposure to TBEV and/or an antigenically similar tick-borne flavivirus is documented for the first time in blood donors in Zonguldak in Northern Anatolia. Probable cases of TBE have also been identified from Central Anatolia. The epidemiology of TBEV activity in Turkey needs to be assessed and benefits of vaccination for general population, risk groups or travellers must be considered.
\end{abstract}

\section{Introduction}

Tick-borne encephalitis virus (TBEV), an enveloped, positive-strand RNA virus classified in Flaviviridae, is the aetiological agent of tick-borne encephalitis (TBE), a potentially fatal central nervous system (CNS) infection of humans (Monath, 1990). The virus, transmitted mainly by Ixodid ticks, is endemic in many areas of Europe and Asia (Suss, 2003). A significant increase has been noted for TBE morbidity from 1974 to 2003 and the virus is currently detected in previously unaffected regions (Randolph, 2002; Broker and Gniel, 2003; Suss, 2003; Mansfield et al., 2009). A very efficient vaccine, which has been implemented in vaccination programmes in various countries and has successfully decreased the morbidity associated with the infection, is available to prevent TBE (Kunz, 2003; Mansfield et al., 2009). The information on TBEV activity in Turkey, which shares certain climatic and ecological conditions with the endemic zones, is limited (Suss, 2008). The initial evidence of TBEV-related infections in Turkey dates back to 1968, when three patients with meningoencephalitis had been retrospectively diagnosed as TBE via rises in the haemagglutination inhibiting antibody titres (Serter, 1968). Plaque reduction neutralization test (PRNT)-confirmed seroprevalence rates of $1.21 \%$ and $1.29 \%$ were reported from 1074 humans and 155 sheep from Aegean (western Anatolia) and Mediterranean (southern Anatolia) regions of Turkey in 1980 and 1971 respectively (Radda, 1971; Serter, 1980). Recently, TBEV reactive IgGs have been detected by enzyme-linked immunosorbent assay (ELISA) in $1.4 \%$ of 274 persons with the history of tick bites and in 7 of 39 persons under investigation for Crimean Congo Hemorrhaggic Fever from Central/Northern Anatolia, where a probable case with IgM reactivity has also been announced (Uyar et al., 2007; Esen et al., 2008). We have documented the evidence for possible TBEV infections in Southeastern Turkey 
(Ergunay et al., 2007). However, these recent studies cover only relatively small groups and the serological assay results have not been confirmed and thus viral activity in the region could not be firmly established. Therefore, we aimed to identify TBEV exposure in healthy blood donors from Central/Northern Anatolia where no previous seroprevalence data are available and the role of TBEV in CNS infections from Central Anatolia.

\section{Materials and Methods}

\section{Sera from blood donors}

A total of 2454 sera, collected from volunteer blood donors after informed consent between January and April 2009 at four major branches (Ankara, Konya, Eskişehir and Zonguldak provinces, Table 1) affiliated with the Turkish Red Crescent Middle Anatolia Regional Blood Center, were included. The distribution of sera was determined according to the population density of each region (Fig. 1). Donor sampling was performed at all branches and by permanent and mobile donation units covering all regions of the particular province. Ankara is the capital and second most densely populated city in Turkey. Mean age of the study groups from each region were Ankara: 32.51 years (range: 18-64, standard deviation: 13.51), Konya: 34.84 (range: 20-62, standard deviation: 14.02), Eskisehir: 38.43 (range: 19-61, standard deviation: 13.76) and Zonguldak: 30.22 (range: 19-59, standard deviation: 12.89). All participants filled out a survey questionnaire to identify various risk factors for vector-borne infections and Flavivirus vaccinations. All sera were transported on dry ice and stored in aliquots in )20 and $) 80^{\circ} \mathrm{C}$.

\section{Serum-cerebrospinal fluid samples from patients}

Paired serum and cerebrospinal fluid (CSF) samples obtained from 108 adult patients with the preliminary diagnosis of aseptic meningitis/encephalitis of presumed viral aetiology were evaluated retrospectively. The samples were stored in aliquots in $) 20$ and $) 80^{\circ} \mathrm{C}$ for future analysis at the Hacettepe University Hospital Central Laboratory. They were collected between April and October 2009 and cultures for Mycobacterium tuberculosis and other causes of bacterial meningitis, as well as polymerase chain reaction (PCR) assays for Herpes viruses, were negative. Clinical history and laboratory data of the patients were retrieved from medical records.

The study was performed after approval from Hacettepe University Medical Ethics Committee, in compliance with the World Medical Association Declaration of Helsinki and according to the blood donation official guidelines of Turkish Red Crescent Society as approved by Turkish Ministry of Health.

\section{Blood donor surveillance}

Sera from blood donors were analysed quantitatively for TBEV IgG by a commercial ELISA (Anti-TBE Virus IgG ELISA; Euroimmun, Lubeck, Germany) according to the manufacturer's instructions. Test results were expressed in relative units per millilitre $(\mathrm{RU} / \mathrm{ml})$, calculated according to the standard curve formed by including three calibrator sera with known antibody titres at each run. Samples with antibody levels of $\ddagger 20 \mathrm{RU} / \mathrm{ml}$ were considered positive and $10-19 \mathrm{RU} / \mathrm{ml}$ were considered borderline. Samples with positive/borderline TBEV IgG ELISA results were further tested with a commercial TBEV IgM ELISA assay (Anti-TBE Virus IgM ELISA; Euroimmun) according to the manufacturer's instructions.

\section{TBEV plaque reduction neutralization test}

Sera from blood donors that were positive/borderline for TBEV IgG were tested for neutralizing antibodies by PRNT to confirm specificity. Initially, PS cells $\left(5 \times 10^{5}\right.$ cells $\left./ \mathrm{ml} ; 300 \mathrm{II}\right)$ were seeded in a 24-well plate. The sera and the controls were mixed 1:5 with L15 medium, incubated for 30 min at $56^{\circ} \mathrm{C}$ and 2-fold dilution series $(1: 5$ to $1: 160)$ were prepared. A dilution of $1.67 \times 10^{2} \mathrm{PFU} / \mathrm{mL}$ of the TBE strain K23 was prepared and each serum dilution was mixed with an equal amount of virus (250 II), resulting in final dilutions of $1: 10$ to $1: 320$. For the virus control, the virus was mixed $1: 2$ with L15 medium. All dilutions were incubated for $30 \mathrm{~min}$ at $37^{\circ} \mathrm{C}$ and $200 \mathrm{II}$ was then added to the seeded cells. The plates were incubated for $4 \mathrm{~h}$ at $37^{\circ} \mathrm{C}$, overlaid with $1.6 \%$ carboxymethyl cellulose in L15 medium and incubated for 4 days at $37^{\circ} \mathrm{C}$. The cells were fixed for 30 min with $3.7 \%$ formaldehyde, stained with naphthalene-black for another $30 \mathrm{~min}$ and the plate was washed with water and dried. The plaques were counted and the $90 \%$ plaque reducing neutralization titre ( $\left.\mathrm{NT}_{90}\right)$ was calculated as described previously (Hierholzer and Killington, 1996) 
Screening of sera-CSF pairs from patients

Samples from aseptic meningitis/encephalitis patients were tested for TBEV and Borrelia IgG/lgM via commercial indirect immunofluorescence tests (IIFTs) and ELISAs according to the manufacturer's instructions respectively (Anti-TBE Virus IgM/lgG IIFT, Anti-TBE Virus IgM/lgG ELISA, AntiBorrelia+VIsE IgM/IgG ELISA; Euroimmun). Borrelia IgG/lgM positive results in sera were further tested via Anti-Borrelia EUROLINERN-AT (Euroimmun) for confirmation.

\section{Evaluation of TBEV positive sera-CSF samples}

Samples with positive for TBEV IgM/lgG results were evaluated by commercial IIFT and ELISA tests (Anti-West Nile virus IgM/IgG IIFT, Anti-West Nile virus IgM/IgG ELISA, Anti-Measles virus IgG ELISA; Euroimmun) to identify cross-reactions and/or other causes of CNS infections. Intrathecal antibody production for TBEV, Borrelia and Measles virus was determined for positive samples with specific commercial ELISA tests (Anti-TBE Virus ELISA IgM/lgG in CSF, Anti-Borrelia+VIsE IgM/lgG ELISA in CSF, Anti-Measles Virus IgG in CSF; Euroimmun). All assays were performed and evaluated according to the manufacturer's instructions. Samples reactive for West Nile Virus IgM were further evaluated by a realtime reverse transcription PCR as described previously (Ergunay et al., 2009).

\section{Results}

TBEV seroprevalence in blood donors

A total of 47 samples $(47 / 2454 ; 1.9 \%)$ yielded positive/borderline results for TBEV IgG by ELISA. In 25 persons with IgG reactivity $(25 / 47 ; 53.1 \%)$, risk factors for tick-borne infections (tick exposure, consumption of unpasteurized milk, outdoor working/tracking/residing in forests or tick-infested areas) were identified. None of these donors had a history of TBE/Yellow Fever/Japanese Encephalitis vaccination or travelling to TBE-endemic regions. All samples were negative for TBEV IgM.

Plaque reduction neutralization test identified only one sample $(1 / 47 ; 2.1 \%)$ to possess neutralizing antibodies for TBEV (NT90:17). The confirmed sample was obtained from a 27-year-old male donor residing in Kilimli neighbourhood of Zonguldak province, Black Sea region of Turkey. At the time of donation, he was employed as a construction worker and had outdoor activities in the forest /tickinfested areas, but had not recalled a tick-bite or had no means of contact with sheep. The distribution of ELISA/PRNT results according to the site of blood donation is given in Table 1.

\section{TBEV/Borrelia detection in patients}

Tick-borne encephalitis virus IgM was identified by ELISA in seven, by IIFT in two serum samples (total: 9/ 108; $8.3 \%$ ). Sera with IgM positivity via IIFT ( $\mathrm{n}: 2$ ) were accompanied by a borderline IgM ELISA and a positive IgG IIFT result respectively. In an ELISA IgM positive sample, IgG was also positive by IIFT+ELISA, thus, a total number of two samples $(2 / 108 ; 1.8 \%)$ have been found reactive for $\lg M+\lg G$ by various assays (Table. 2). One sample with TBEV IgG reactivity only was also revealed by ELISA+IIFT. Intrathecal synthesis and presence of antibodies in CSF could not be demonstrated for any of the corresponding serum $\operatorname{lgM} / \mathrm{lgG}$ reactive samples.

Three serum samples with TBEV IgM reactivity were borderline for West Nile Virus IgM by ELISA or IIFT (Cases 2, 3 and 7; Table 2). These were evaluated for West Nile Virus RNA and found to be negative. In two samples reactive for TBEV IgM and measles virus IgGs, specific antibody production against measles virus was identified in CNS and these were excluded from the review for the presumed TBE cases.

Anti-Borrelia IgM and IgGs were detected in 14 (14/ 108; 12.9\%) and $8(8 / 108 ; 7.4 \%)$ sera by ELISA respectively, where one sample was positive for both IgM and IgG. None of the samples could be confirmed by the commercial line blot assay utilizing native and recombinant Borrelia antigens and no intrathecal antibody production was identified.

Patient history, clinical laboratory data could be retrieved and reviewed in six of eight TBEV IgM positive individuals and only laboratory test results were available for two cases. All persons had fever $\left(>37.8^{\circ} \mathrm{C}\right)$ and normal liver function tests at the time of presentation. Clinical and laboratory data of TBEV seroreactive cases are summarized in Table 2. 


\section{Discussion}

Tick-borne encephalitis is an emerging disease and the most important flavivirus infection of the CNS in Europe and Russia (Pugleise et al., 2007). TBE incidence has been observed to increase in both high and low risk areas in certain endemic countries and new TBE foci have appeared possibly due to complex interactions among climatic, social and ecological factors (Haglund, 2002; Randolph, 2002; Sumilo et al., 2008). Very scarce data on neutralization-confirmed TBEV activity are currently available from Turkey (Radda, 1971; Serter, 1980). This study was designed to reveal virus exposure in healthy blood donors and the impact of TBEV in cases of aseptic meningitis/encephalitis of unknown aetiology, retrospectively screened to identify TBE-induced syndromes. TBEV IgG/lgMs were determined via commercial ELISA/IIFTs with enhanced specificity/sensitivity and seroprevalence results were confirmed by PRNT. To our knowledge, this is the largest study investigating human TBE exposure from Turkey and the first to reveal TBE activity in Central/ Northern Anatolia.

The only human seroprevalence data on TBEV come from Aegean region (western border) of Turkey where antibodies were detected by haemagglutination inhibition $(\mathrm{HI})$ assay and were confirmed by neutralization in 13 of 1074 residents (1.21\%) of Izmir province (Serter, 1980). Evidence for viral activity in Mediterranean region (southern Turkey) had also been provided, by detecting TBEV neutralizing antibodies in $1.29 \%(2 / 155)$ of sheep in Hatay province (Radda, 1971). Although not confirmed, TBE IgG has also been detected by ELISA in 1.1\% (3/274) persons with a history of tick bite from Central Anatolia, raising the possibility of viral activity in this region (Uyar et al., 2007). In this study, we have investigated TBEV exposure in blood donors at four major branches (in Ankara, Konya, Eskisehir and Zonguldak provinces) of Turkish Red Crescent Middle Anatolia Regional Blood Center, covering a relatively large sampling zone in central and northwestern Anatolia. Although ELISA reactive samples have been detected at a rate of $1.83 \%(45 / 2454)$, no confirmed exposure has been identified from Ankara, Konya, Eskisehir regions (Table 1). One of the two ELISA positive samples from Zonguldak in the Black Sea region has been reactive in PRNT, providing the only confirmed TBEV IgG in our study, and indicates virus activity in the northwestern part of Turkey (Table 1). The exposed person, although not recalling any tick bites, had stated to have outdoor activities in the forest/tick-infested areas. Black Sea region is an established habitat for Ixodid ticks; the ecological and climatic conditions of the region generally favour tick activity (Aydin and Bakirci, 2007).

Ixodes ricinus ticks have been widely recognized as the major vector for European TBEV subtype and Ixodes persulcatus is mainly responsible for transmitting Siberian/ Far Eastern TBEV subtypes (Charrel et al., 2004). It is generally accepted that other Ixodid species such as Ixodes hexagonus and certain Haemaphysalis/Dermacentor species are competent as vectors and may transmit the virus (Suss, 2003). Turkey's tick fauna has been shown to include about 32 species and Ixodes spp. have been detected mostly in Northern Turkey, where the amount of rainfall during the year is the highest and intensive forests are the predominant vegetation (Aydin and Bakirci, 2007). Nevertheless, in addition to the Black Sea region, I. ricinus activity has been shown to be present in Mediterranean, Aegean and east/southeast Anatolia (Aydin and Bakirci, 2007). TBEV has not yet been detected in ticks in Turkey and the vector species for TBEV transmission is, therefore, not validated. The consumption of unpasteurized goat or cow milk, which is widely practised especially in rural areas in Turkey, is also verified as an alternative route for TBEV infection (Monath, 1990) and therefore may be acting as a potential means of transmission. The probable impact of this practice is also reflected in our blood donor risk assessment survey where in 25 TBEV IgG positive/borderline donors with risks for tick-borne diseases, eight persons $(32 \%)$ have stated their frequent use of unpasteurized milk/milk products (data not shown).

In retrospective screening of serum and CSF samples from 108 patients with aseptic meningitis/encephalitis of unknown aetiology, we have identified TBEV serum IgM reactivity in eight patients $(7.4 \%)$, accompanied by $\operatorname{lgG}$ in two of the eight sera. No reactivity in CSF antibody assays was observed. Assays to detect viral RNA have not been performed due to lack of sufficient amounts of samples and as viral nucleic acid/antigen detection is unsuccessful in the majority of the neurological phase of the infection after the immune response have been mounted (Holzmann, 2003). As the study was conducted by using previously stored samples, investigation of the cases was confined to the medical records, and convalescent serum samples were not available for confirmation. As TBE vaccines have been neither registered nor used in Turkey, and no record of any other Flaviviral vaccination or travelling to endemic regions was available, the TBEV IgM seroreactivity observed in the patients is very likely to indicate exposure to TBE and strongly associated with the documented CNS infections. The identification of the history of a recent tick bite and presence of a non-specific febrile disease preceding the initiation of CNS symptoms as well as IgG reactivity further 
supported the diagnosis in certain cases (Table 2) (Holzmann,2003). It is generally accepted that detection of $\lg G$ and/or IgM in serum in a clinically compatible case warrants the diagnosis of probable or confirmed TBE case (Holzmann, 2003; Gunther and Lindquist, 2005; Stefanoff et al., 2005). Detection of TBEV IgM is also said to be sufficient for cases with presentations

in routine clinical practice in endemic regions (Gunther and Lindquist, 2005). These definitions are harder to comprehend for Turkey due to the paucity of published TBE reports, and virus epidemiology being not completely understood. Nevertheless, it is evident that for at least two cases in the study group, all case definition requirements were fulfilled and the diagnosis is further supported by the medical history as well as laboratory results (Table 2).

Co-infections of TBEV and Borrelia have been shown to occur and have already been revealed in several countries in Europe (Korenberg, 2004). It is suggested that in cases with TBE-related CNS disease, infection with Borrelia should also be considered (Cimperman et al., 1998). Although we have identified Borrelia antibodies in 21 individuals (21/108; 19.4\%), none could be confirmed and intrathecal antibodies have not been identified; thus, neuroborreliosis was ruled out in the study group. In three patients with TBEV IgM reactivity, borderline results for West Nile Virus IgM have been observed, but viral RNA could not be detected. West Nile Virus has been documented previously to circulate in Central Anatolia (Ergunay et al., 2009) and may also cause CNS symptoms and serological cross-reactivity (Monath, 1990; Allwinn et al., 2002).

The first TBE case report from Aegean region, Turkey was published locally in 1968, where significant increase in TBEV antibody titres in the $\mathrm{HI}$ assay was detected in three patients with CNS infections from the Aegean region. All persons had presented predominantly with meningeal symptoms and had recovered without sequelae (Serter, 1968). We have also identified TBEV IgM+lgG reactivity in six persons from southeastern Turkey, but the diagnosis of TBE could not be suggested due to the lack of relevant clinical data (Ergunay et al., 2007). Esen et al. (2008) identified a probable case with only IgM positivity in Tokat province in the Black Sea region with a history of tick bite which had an unfavourable clinical course, resulting in mortality. The clinical presentation and progression observed for the probable TBE cases identified in our study are generally mild, and meningitic/ meningomyelitic symptoms predominate (Table 2). Majority of the patients (7/8) had recovered without sequelae, whereas in one case, muscle paresis had persisted on discharge from the hospital. Thus, it can be suggested that the clinical course of the suspected TBE cases was similar to TBE observed with European subtype of the virus (Gritsun et al.,2003; Haglund and Gunther, 2003).

An acute form of encephalomyelitis was recognized in sheep in the Gebze area of northwestern Turkey in the 1960s and the causative virus, called Turkish Tick-borne Encephalitis or Turkish sheep encephalitis virus (TSEV), was identified (Hartley et al.,1969; Grard et al., 2007). TSEV, initially considered as a subtype of Louping ill virus (LIV), is shown to be genetically more closely related to the tick-borne encephalitis complex viruses (especially the European subtype of TBEV) than to LIV, but despite common biological properties, TSEV is considered a subtype neither of LIV nor of TBEV (Whitby et al., 1993; Grard et al., 2007). The epidemiology of TSEV in Turkey has not been studied in humans, animals or tick vectors and no data relevant to the vertebrate exposure are available. TSEV has not yet been associated with CNS diseases in humans. Serological studies on the structural relationship of TSEV to other viruses of the TBE complex revealed that antigenic variation existed between TSEV and other TBE viruses (Hambleton et al., 1983; Stephenson et al., 1984). Nevertheless, cross-reactions in commercial serological tests as well as in PRNT cannot be entirely ruled out. More data on TSE are required to estimate the occurence/extent of human exposures as well as the impact on animal health in Turkey.

Turkey, currently, is not an established TBE focus and awareness among physicians and diagnostic microbiologists is low; therefore, probable TBEV-related clinical conditions are likely to be overlooked. No established surveillance programmes related to tick epidemiology exist in Turkey, but studies by various groups have aided to reveal the vector ecology and epidemiology of ticks (Aydin and Bakirci, 2007). Implementation of surveillance programmes and identification of high risk areas for animals and humans are needed for a better understanding of tick-borne diseases in Turkey.

In conclusion, confirmed exposure to TBEV and/or an antigenically similar flavivirus is documented for the first time in healthy blood donors in Zonguldak in Northern Anatolia. Probable TBE-related cases of CNS infections have also been identified from Central Anatolia. The distribution of TBEV/TSEV activity in Turkey awaits assessment and benefits of TBE vaccination for general population, risk groups or travellers must be considered. 


\section{Acknowledgements}

This project was partially supported by Turkish Red Crescent Society and Hacettepe University Research Fund (Project No. 08 O 101 001). The authors acknowledge Katja Steinhagen and Aykut Ozkul for support, Susanne Kass, Anja Kietzmann and Irfan Atmaca for excellent technical assistance. Preliminary surveillance results from the blood donors were presented as a poster at the $12^{\text {th }}$ Annual Meeting of the European Society for Clinical Virology between 27 and 30 September 2009.

\section{References}

Allwinn, R., H. W. Doerr, P. Emmerich, H. Schmitz, and W. Preiser, 2002: Cross-reactivity in flavivirus serology: new implications of an old finding? Med. Microbiol. Immunol. 190, 199-202.

Aydin, L., and S. Bakirci, 2007: Geographical distribution of ticks in Turkey. Parasitol. Res. 101, 163166.

Broker, M., and D. Gniel, 2003: New foci of tick-borne encephalitis virus in Europe: consequences for travellers from abroad. Travel. Med. Infect. Dis. 1, 228-232.

Charrel, R. N., H. Attoui, A. M. Butenko, J. C. Clegg, V. Deubel, T. Frolova, E. A. Gould, T. S. Gritsun, F. X. Heinz, M. Labuda, V. A. Lashkevich, V. Loktev, A. Lundkvist, D. V. Lvov, C. W. Mandl, M. Niedrig, A. Papa, V. S. Petrov, A. Plyusnin, S. Randolph, J. Süss, V. I. Zlobin, and X. de Lamballerie, 2004: Tick-borne virus diseases of human interest in Europe. Clin. Microbiol. Infect. 10, 1040-1055.

Cimperman, J., V. Maraspin, E. Lotric-Furlan, T. Ruzic-Sabljic, R. N. Avsic-Zupanc, and F. Strle, 1998: Concomitant infection with tick-borne encephalitis virus and Borrelia burgdorferi sensu lato in patients with acute meningitis or meningoencephalitis. Infection 26, 160-164.

Ergunay, K., N. Ozer, D. Us, A. Ozkul, F. Simsek, and S. Kaynas, 2007: Seroprevalence of West Nile virus and tickborne encephalitis virus in Southeastern Turkey: first evidence for tick-borne encephalitis virus infections. Vector Borne Zoonotic Dis. 7, 157-161.

Ergunay, K., M. B. Saygan, S. Aydogan, D. Menemenlioglu, H. M. Turan, A. Ozkul, and D. Us, 2009: West Nile Virus seroprevalence in blood donors from Central Anatolia, Turkey. Vector Borne Zoonotic Dis. (in press). doi: 10.1089/ vbz.2009.0130.

Esen, B., A. Gozalan, N. Coplu, F. S. Tapar, R. Uzan, T. Aslan, M. Ertek, T. Buzgan, and L. Akin, 2008: The presence of tick-borne encephalitis in an endemic area for tick-borne diseases,Turkey. Trop. Doct. 38, 27-28.

Grard, G., G. Moureau, R. N. Charrel, J. J. Lemasson, J. P. Gonzalez, P. Gallian, T. S. Gritsun, E. C. Holmes, E. A. Gould, and X. de Lamballerie, 2007: Genetic characterization of tick-borne flaviviruses: new insights into evolution, pathogenetic determinants and taxonomy. Virology 361, 80-92.

Gritsun, T. S., P. A. Nuttall, and E. A. Gould, 2003: Tickborne flaviviruses. Adv. Virus Res. 61, 317371.

Gunther, G., and L. Lindquist, 2005: Surveillance of tick-borne encephalitis in Europe and case definition. Euro. Surveill. 10, 510.

Haglund, M., 2002: Occurence of TBE in areas previously considered being non-endemic: Scandinavian data generate an international study by the International Scientific Working Group for TBE (ISW-TBE). Int. J. Med. Microbiol. 291, 50- 54.

Haglund, M., and G. Gunther, 2003: Tick-borne encephalitispathogenesis, clinical course and longterm follow-up. Vaccine 21, 11-18.

Hambleton, P., J. R. Stephenson, A. Baskerville, and C. N. Wiblin, 1983: Pathogenesis and immune response of vaccinated and unvaccinated rhesus monkeys to tick-borne encephalitis virus. Infect. Immun. 40, 995-1003.

Hartley, W. J., W. B. Martin, F. Hakiolu, and S. T. E. Chifney, 1969: A viral encephalitis of sheep in Turkey. Pendik Inst. J. 2, 89-100.

Hierholzer, J. C., and R. A. Killington, 1996: Virus isolation and neutralization. In: Mahy, B. W. J., and H. O. Kangro (eds), Virology Methods Manual, 1st edn, pp. 25-46. Academic Press, San Diego, CA.

Holzmann, H., 2003: Diagnosis of tick-borne encephalitis. Vaccine 21, 36-40.

Korenberg, E. I., 2004: Problems in the study and prophylaxis of mixed infections transmitted by ixodid ticks. Int. J. Med. Microbiol. 293, 80-85.

Kunz, C., 2003: TBE vaccination and the Austrian experience. Vaccine 21, 550-555.

Mansfield, K. L., N. Johnson, L. P. Phipps, J. R. Stephenson, A. R. Fooks, and T. Solomon, 2009: Tick-borne encephalitis virus - a review of an emerging zoonosis. J. Gen. Virol. 90, 1781-1794.

Monath, T. P., 1990: Flaviviruses. In: Fields, B. N., and D. M. Knipe (eds), Virology, 2nd edn, pp. 763814. Raven Press, New York, NY. 
Pugleise, A., T. Beltramo, and D. Torre, 2007: Emerging and re-emerging viral infections in Europe. Cell Biochem. Funct. 25, 1-13.

Radda, A., 1971: Antibodies against group A and B Arboviruses in domestic animals from Turkey. E.U. Tıp Fak. Mecmuasi 10, 227-230.

Randolph, S., 2002: The changing incidence of tickborne encephalitis in Europe. Euro. Surveill. 6, 1953.

Serter, F., 1968: Tick-borne meningo-encephalitis cases in Izmir area. E.U. Tıp Fak. Mecmuasi 7, 113.

Serter, D., 1980: Present status of arbovirus sero-epidemiology in the Aegean region of Turkey. Zentralbl. Bakteriol. S9, 155-161.

Stefanoff, P., M. Eidson, D. L. Morse, and A. Zielinski, 2005: Evaluation of tickborne encephalitis case classification in Poland. Euro. Surveill. 10, 23-25.

Stephenson, J. R., J. M. Lee, and P. D. Wilton-Smith, 1984: Antigenic variation among members of the tick-borne encephalitis complex. J. Gen. Virol. 65, 81-89.

Sumilo, D., A. Bormane, L. Asokliene, V. Vasilenko, I. Golovljova, T. Avsic-Zupanc, Z. Hubalek, and S. Randolph, 2008: Socio-economic factors in the differential upsurge of tick-borne encephalitis in Central and Eastern Europe. Rev. Med. Virol. 18, 81-95.

Suss, J., 2003: Epidemiology and ecology of TBE relevant to the production of effective vaccines. Vaccine 21, 19-35.

Suss, J., 2008: Tick-borne encephalitis in Europe and beyond - the epidemiological situation as of 2007. Euro. Surveill. 13, 18916.

Uyar, Y., A. Akcali, A. Carhan, E. Ozkaya, and M. Ertek, 2007: Seroprevalence of tick-borne encephalitis virus (TBEV) among cases with tick bite history in Turkey. Turk Hij. Deney. Biyol. Derg. 64, 21-25.

Whitby, J. E., S. N. Whitby, A. D. Jennings, J. R. Stephenson, and A. D. T. Barrett, 1993: Nucleotide sequence of the envelope protein of a Turkish isolate of tick-borne encephalitis (TBE) virus is distinct from other viruses of the TBE virus complex. J. Gen. Virol. 74, 921-924. 


\section{Tables and Figures}

Table 1 Distribution of samples according to the region of blood donation and TBEV antibody results by ELISA and PRNT

\begin{tabular}{|c|c|c|c|c|c|c|}
\hline \multirow[b]{2}{*}{ Sampling region } & \multirow{2}{*}{$\begin{array}{l}\text { Number of } \\
\text { samples }\end{array}$} & \multirow{2}{*}{$\begin{array}{l}\text { Gender } \\
\text { (female/male) }\end{array}$} & \multirow{2}{*}{$\begin{array}{l}\text { Place of residence } \\
\text { (urbarvrural) }\end{array}$} & \multicolumn{2}{|c|}{ TBEV ELISA } & \multirow{2}{*}{$\begin{array}{l}\text { PRNT } \\
\text { confirmed (\%) }\end{array}$} \\
\hline & & & & $\lg M(\%)$ & $\lg G(\%)$ & \\
\hline Ankara $\left(39^{\circ} 56^{\prime} \mathrm{N}-32^{\circ} 52^{\prime} \mathrm{E}\right)$ & 1351 & $83 / 1268$ & $1255 / 96$ & $0(0)$ & $34(2.51)$ & $0(0)$ \\
\hline Konya $\left(37^{\circ} 52^{\prime} \mathrm{N}-32^{\circ} 31^{\prime} \mathrm{E}\right)$ & 670 & $12 / 658$ & $533 / 137$ & $0(0)$ & $9(1.34)$ & $0(0)$ \\
\hline Eskisehir $\left(39^{\circ} 46^{\prime} \mathrm{N}-30^{\circ} 32^{\prime} \mathrm{E}\right)$ & 235 & $16 / 219$ & $168 / 67$ & $0(0)$ & $2(0.85)$ & $0(0)$ \\
\hline Zonguldak $\left(41^{\circ} 27^{\prime} \mathrm{N}-31^{\circ} 49^{\prime} \mathrm{E}\right)$ & 198 & $4 / 194$ & $117 / 81$ & $0(0)$ & $2(1)$ & $1(0.5)$ \\
\hline Total & 2454 & $115 / 2339$ & $2073 / 381$ & $0(0)$ & $47(1.91)$ & $1(0.04)$ \\
\hline
\end{tabular}

TBEV, tick-borne encephalitis virus; ELISA, enzyme-linked immunosorbent assay; PRNT, plaque reduction neutralization test.

Table 2 Clinical symptoms and laboratory data of TBE seroreactive cases

\begin{tabular}{|c|c|c|c|c|c|c|c|c|c|c|c|c|c|c|c|c|}
\hline \multirow[b]{2}{*}{ Case } & \multirow{2}{*}{$\begin{array}{l}\text { Age/gender/ } \\
\text { place of } \\
\text { residence }\end{array}$} & \multicolumn{2}{|c|}{$\begin{array}{l}\text { TBE } \\
\text { ELISA } \\
\text { (serum) }\end{array}$} & \multicolumn{2}{|c|}{$\begin{array}{l}\text { TBE ॥FT } \\
\text { (serum) }\end{array}$} & \multirow{2}{*}{$\begin{array}{l}\text { Tick } \\
\text { bite }\end{array}$} & \multirow{2}{*}{$\begin{array}{l}\text { Flavivivrus } \\
\text { vaccination/ } \\
\text { travel to } \\
\text { endemic zones* }\end{array}$} & \multirow{2}{*}{$\begin{array}{l}\text { CSF } \\
\text { pleocytosis }\end{array}$} & \multirow[b]{2}{*}{ Biphasiccourse } & \multirow{2}{*}{$\begin{array}{l}\text { Meningeal } \\
\text { signs }\end{array}$} & \multirow{2}{*}{$\begin{array}{l}\text { Paresis of } \\
\text { acute onset }\end{array}$} & \multirow{2}{*}{$\begin{array}{l}\text { Sensorial } \\
\text { impaiment }\end{array}$} & \multirow{2}{*}{$\begin{array}{l}\text { Cranial nerve } \\
\text { involvement }\end{array}$} & \multirow{2}{*}{$\begin{array}{l}\text { Cerebellar } \\
\text { symptoms }\end{array}$} & \multirow{2}{*}{$\begin{array}{l}\text { Encephalitic } \\
\text { symptoms }{ }^{\dagger}\end{array}$} & \multirow{2}{*}{$\begin{array}{l}\text { Neurological } \\
\text { sequelae }\end{array}$} \\
\hline & & $\lg M$ & $\lg G$ & $\lg M$ & $\lg G$ & & & & & & & & & & & \\
\hline 1 & 35/M/Eskisehir & + & + & - & + & + & - & + & - & + & + & - & - & - & - & - \\
\hline 2 & 31/M/Ankara & - & - & + & + & - & - & + & + & + & - & - & - & - & - & - \\
\hline 3 & 21/M/Ankara & + & - & + & - & - & - & + & - & + & - & - & - & - & - & - \\
\hline 4 & 54/F/Ankara & + & - & - & - & - & - & + & - & - & + & + & + & - & - & - \\
\hline 5 & 52/F/Ankara & + & - & - & - & - & - & + & - & - & - & - & - & - & - & - \\
\hline 6 & 63/M/Ankara & + & - & - & - & - & - & - & - & - & + & - & - & + & + & $t^{*}$ \\
\hline 7 & 40/F/Ankara & + & - & - & - & n.i. & n.i. & n.i. & n.i. & n.i. & n.i. & n.i. & n.i. & n.i. & n.i. & n.i. \\
\hline 8 & 21/F/Konya & + & - & - & - & n.i. & n.i. & n.i. & n.i. & n.i. & n.i. & n.i. & n.i. & n.i. & n.i. & n.i. \\
\hline
\end{tabular}

TBE, tick-borne encephalitis; ELISA, enzyme-linked immunosorbent assay; IIFT, indirect immunofluorescence test; CSF, cerebrospinal fluid; n.i., no information.

* Vaccination against TBE, Yellow Fever, Japanese Encephalitis, travel to TBE and/or Dengue endemic areas.

${ }^{\dagger}$ Include alterations of consciousness, convulsions, muscle hyperkinesia, tremors and vertigo.

${ }^{\ddagger}$ Persisting paralysis.

Figure 1 Map showing the blood donor sampling regions in the study (see Materials and Methods for details).
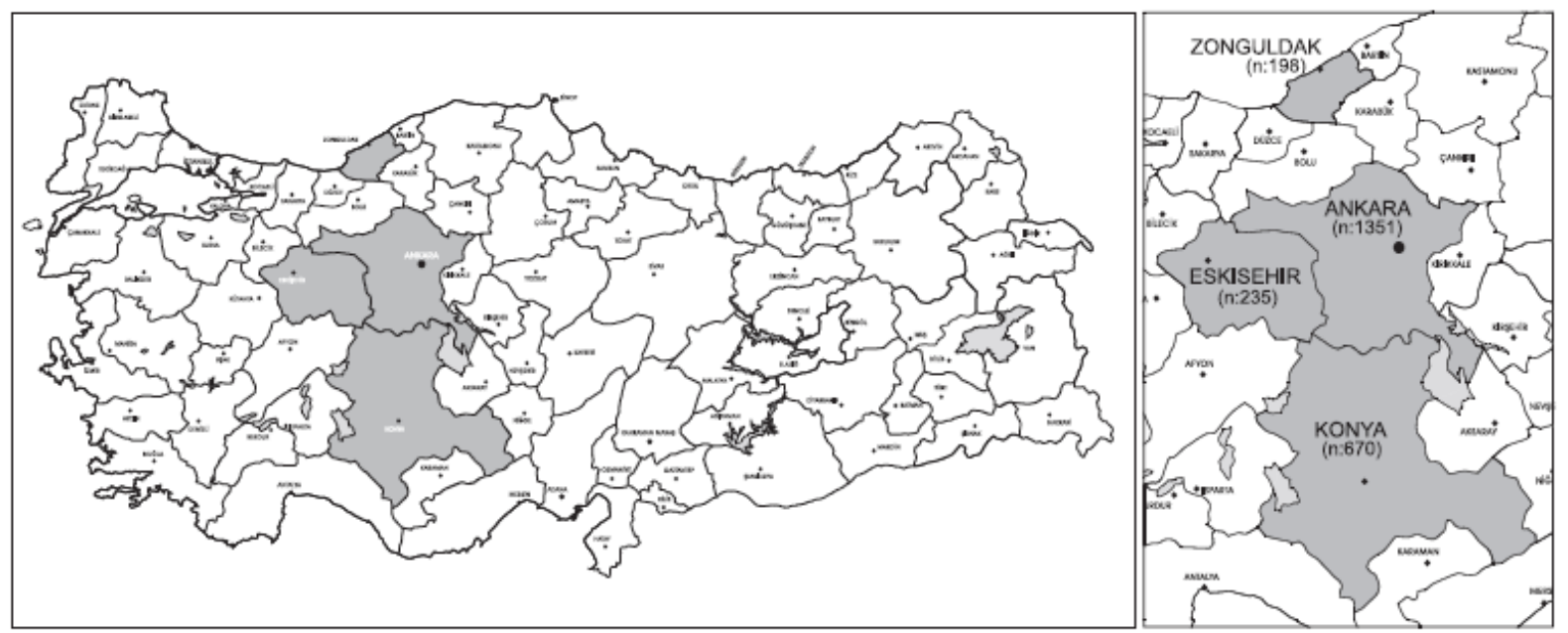